学術論文

\title{
全置換型磁気浮上人工心臟と流量バランス制御
}

\section{Total Artificial Heart with a Single Magnetically Suspended Motor and Its Flow Balance Regulation}

\author{
山田＼cjkstart悠" ${ }^{*}$ (正員), 増澤 徹 ${ }^{* 1}$ (正員), Daniel L Timms ${ }^{* 2}$
}

Yu YAMADA， Toru MASUZAWA (Mem.), Daniel L TIMMS

\begin{abstract}
An innovative Bi-Ventricular Artificial Heart (IB-Heart) has been successfully developed with a single magnetically suspended motor. The device has auto flow regulation function which reacts to atrial pressure change in order to balance the flow rate of left and right pump. The zero power control is adopted to control axial position of levitated impeller in the IB-Heart. The rate of change of the axial position of the impeller on the atrial pressure change is the key factor of this device's flow regulation function since the flow rate of the pumps is regulated with axial position changing of the levitated impeller. The flow regulating ability of the IB-Heart and the relationship between the rod cross-sectional area and the flow regulation function was investigated. The maglev motor was redesigned with 3-D magnetic field analysis to improve the flow regulation function.
\end{abstract}

Keywords: Total Artificial Heart, Magnetically suspended motor, Flow regulation function, Magnetic suspension

\section{1 緒言}

重篤心不全患者を救う方法に人工心臟の適用があ り，最近では自己心に並列に装着しその機能を補助す る補助人工心臟が臨床応用されている。補助人工心臟 は主に左心のポンプ機能を補助するデバイスであり, 心臟移植を必要としながらも藏器提供者(ドナー)の不 在により移植を受けることができない患者に適用され る。これは，心臟移植までの橋渡し，あるいは心機能 の半永久的な補助を目的とする使用である[1-4]。

しかし，補助人工心藏の適用によって心臟移植に移 行し救命される患者や，新機能が回復する患者がいる 一方，適用患者のうちの一部は埋め込み後に右心不全 を併発することが報告されている[5]。そのため, 補助 人工心臟の適用の拡大によって両心不全患者が増加す ると考えられる。全置換型人工心臓は心室を取り除い て埋め込まれるため, 長期間の耐久性を有しているこ と, 埋め込夕可能なサイズであること, 自己心同様に 左右心のポンプ流量のバランスを取ることが求められ る。近年では軸流ポンプ式の補助人工心臟を二つ埋め 込むことで全人工心臓とする研究が開始されたが，独 立した二つの制御系でいかに左右心室の流量バランス をとるかが課題となっている。

これに対し, 我々は磁気浮上モータの技術を応用し た全置換型人工心藏 IB-Heart (Innovative Bi-Ventricular 連絡先：増澤 徹, テ316-8511 茨城県日立市中成沢 4-12-1, 茨城大学工学部機械工学科,

e-mail:masuzawa@mx.ibaraki.ac.jp

${ }^{* 1}$ 茨城大学 ${ }^{* 2}$ BiVACOR Pty. Ltd.

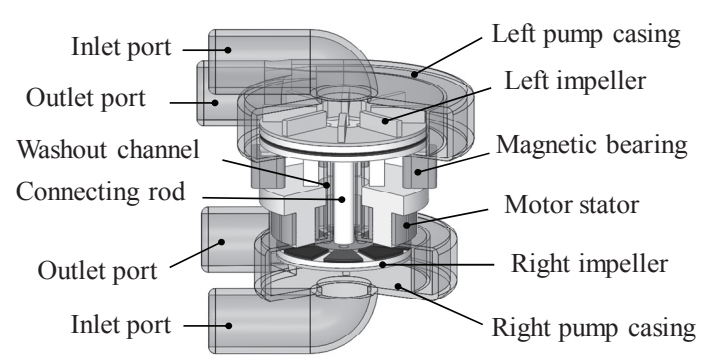

Fig. 1 Structure of IB-Heart.

Artificial Heart) [6]の開発を行っている。IB-Heart では 摺動部における機械的接触がなく, 長寿命, 低溶血, 低血栓である磁気浮上モー夕を採用している。更に, 単一の磁気浮上モータによって二つの遠心ポンプを駆 動することで小型化を図った。浮上インペラの位置制 御にポンプ内流体力とバランスを取るゼロパワー制御 $[6,7,8]$ を用いることにより, 左右の心房圧の変化によ ってポンプ流量を変化させる流量バランス機構を付加 した。

本稿では，IB-Heart のゼロパワー制御を用いた新規 な左右心流量バランス制御方式の確立を目指し，心房 圧変化に対するポンプ駆出性能を評価した。また，左 右心流量バランス制御性能を向上させるために三次元 磁場解析による磁気浮上モータの再設計を行った。

\section{2 方法}

\subsection{IB-Heart の構造}

IB-Heart の概略図を Fig. 1 に示す。内部の構造を示 
すため, ポンプケーシングおよび磁気浮上モータのス テータコアは一部を断面表示としている。ステータコ アは上部が磁気軸受ステータ, 下部がモータステータ である[6,8]。磁気軸受ステータには 90 度間隔に 4 つの 制御用電磁石を, モータステータには 12 突極の電磁石 を配置している。各ステータに対面するように磁気軸 受ロータディスクとモータロータディスクを配置する。 各ロータディスクにはそれぞれ浮上用, 回転用の永久 磁石を取り付ける。2 枚のロータディスクは, ステー タコアの中心の穴を軸方向に貫く連結ロッドによって 結合される。さらに, 各ロータディスクに遠心ポンプ 用のインペラを取り付ける。ロータディスク, 連結ロ ッド, インペラを組み立てたものを浮上インペラと呼 ぶ。また, 左心系のロータディスクとインペラを左心 インペラ, 右心系のロータディスクとインペラを右心 インペラと呼ぶ。

本デバイスの磁気軸受には強力な磁気吸引力と高 い制御性能を併せ持つダブルバイアス型磁気軸受を採 用している[6,8]。浮上インペラは, 磁気軸受によって 軸方向位置と回転軸を除く 2 軸周りの傾きを制御され る。径方向位置は, ステータとロータディスクの間に 働く磁気吸引力によって受動的に支持される。また, モータステータのコイルに三相交流を流して回転磁界 を発生させることで浮上インペラを回転させる。モー 夕永久磁石磁場とステータ電磁石による回転制御磁場 の位相差は $90 \mathrm{deg}$ である。この位相差が 90 度のとき, モータの回転トルクは最大となり, モ一夕の軸方向吸 引力は電流量によらず一定となる 8 [ ] Fig. 2 に磁気浮 上モータの制御系を示す。磁気軸受ステータに取り付 けた 4 つの渦電流変位センサの出力から浮上インペラ の軸方向位置と傾きを算出し, モータステータに取り 付けたホール IC の出力から回転角を算出する。算出し たそれぞれの值に対してデジタル PID 制御を行い, リ ニアアンプを用いて浮上用, 回転用の各コイルに制御 電流を与える。

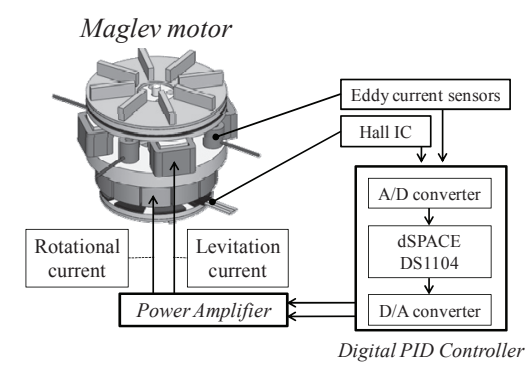

Fig. 2 Control system of maglev motor.

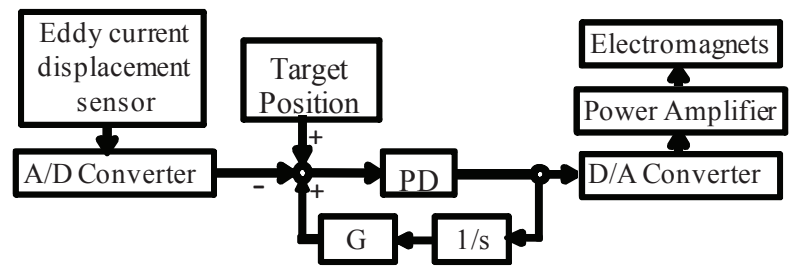

Fig. 3 Schematic diagram of zeropower control.

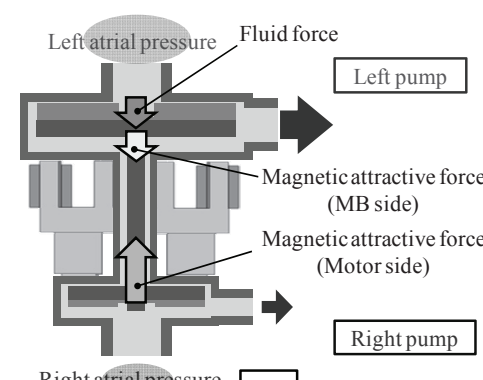

Right atrial pressure (a)

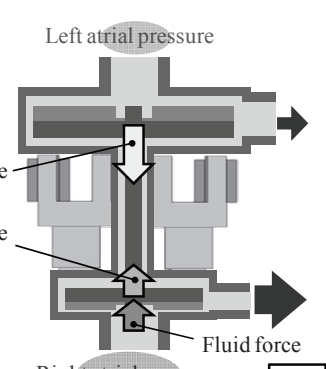

Right atrial pressure
Fig. 4 Relationship between axial position of levitated impeller and pump flow rate.

\section{2 流量バランス制御}

自己心臟は左右心室の流量のバランスを調節する自 己調節機能を有している。しかし, 自己心臟を人工心 臓に置き換えるとその生体制御系から外れるため, 最

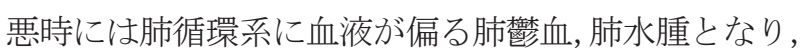
死に至る[9]。そこで，全置換型人工心臓には生体制御 系とは別に左右ポンプ流量のバランスを取る機構が必 要である。IB-Heart は，浮上インペラの軸方向位置に よって左右のポンプ流量が変化する性質と, ゼロパワ 一制御を組み合わせることで，心房圧の大きさに応じ てポンプ流量を変化させて流量バランスを取る。なお, 心房はリザーバの役割を果たすために，切除されず体 内に残されている。

Fig. 3 に示すように, 制御電流值を積分して浮上目 標位置にフィードバック寸ることでゼロパワー制御系 を実現した。本ゼロパワー制御系は遠心ポンプ内の浮 上インペラにかかる流体力と磁気浮上モータで発生す る磁気吸引力の合力がゼロとなるよう浮上インペラの 位置を制御する。ここで, 肺循環系に血液が偏った場 合について考える。その場合, 左心ポンプの流入口が 繋がれている左心房の圧力が高くなる。高くなった左 心房圧は，浮上インペラを左心ポンプから右心ポンプ に向けて下向きに押寸流体力を増加させる。下向き流 体力が増加するとゼロパワー制御は浮上インペラを Fig. 4 (a) のように左心ポンプ側に変位させ, 右心イン ペラとモータステータの間隙を減少させ，上向きの永 
久磁石磁気吸引力を増加させ, 流体力増加分を打ち消 す。このとき, 左心ポンプ側ではインペラとポンプケ ーシングの間隙が小さくなるためにポンプ内二次流れ が減少し, ポンプ流量が増加する。一方, 体循環系に 血液が偏った場合には右心房圧が高くなり, 浮上イン ペラがFig. 4 (b)のように右心ポンプ側に変位し, 右心 ポンプの流量が増加する。このように, 心房圧（流入 口圧）に応じて浮上インペラが変位し, ポンプの流量 を調節することで, 左右心間の流量のバランスを取る ことができる。

本流量バランス制御方法では, (1) 浮上インペラの 浮上位置の変化に対するポンプ流量の変化量と, (2) 心房圧変化に対する浮上インペラの変位量が, 流量バ ランス制御能力を決定する主要素となる。特に(2)の特 性を数值化するために, 浮上インペラの変位量を左右 の心房圧の差の変化量で除した值を流量バランス感受 性 (FB 感受性) $[\mu \mathrm{m} / \mathrm{mmHg}$ と定義する。

\subsection{IB-Heart 試作機の製作}

IB-Heart の人工心臟としての性能を評価するために, 試作機を設計・製作した。Fig. 5 に IB-Heart試作機の 分解図を示す。図中両脇に左右心用のポンプケーシン グを, 中央にアクリルケーシングに封入したステータ コアを示す。アクリルケーシング内に磁気軸受, モー タ用のステータコアを背中合わせに配置した。磁気軸 受ステータコアは外径が $50 \mathrm{~mm}$ であり, 4 つの制御用 電磁石には 200 巻のコイルが巻かれている。材質は電 磁軟鉄 SUY-1 とした。モータステータの 12 突極それ ぞれのコイル巻き数は 60 巻, 材質は圧粉磁心とした。 ステータコアの下に左心インペラと接続ロッド, 右 心インペラを示す。左右のポンプとも, インペラ形状 はセミオープンインペラである。左心ポンプ用インペ ラは外径 $50 \mathrm{~mm}$, 羽根枚数 8 枚, 羽高さ $3.0 \mathrm{~mm}$ であ る。右心ポンプ用インペラは外径 $40 \mathrm{~mm}$, 羽根枚数 4 枚, 羽高さ $1.5 \mathrm{~mm}$ である。右心インペラには中心部 に直径 $3.0 \mathrm{~mm}$ のバランスホールを 4 つ設けている。

左心インペラに付いている連結ロッドをステータ コア中心穴に通して, 右心インペラを接続し, 左右イ ンペラ両側より血液ポンプケーシングを接続して全置 換型人工心藏を構築する。各ステータからロータディ スク表面までの距離が等しいとき, ステータとロータ ディスクの磁気間隙はそれぞれ $2.0 \mathrm{~mm}$ である。ステ ータコア中心穴と連結ロッドの間陌は左心ポンプと右 心ポンプをつなぐウォッシュアウト流路を構成する。
本流路には血栓形成防止のため, 常に左心から右心に 向けて一定量の血液を流す。Fig. 6に組み立て後のデバ イスを示す, デバイスの外径は $76 \mathrm{~mm}$ ，ポート部を除 く幅は $61 \mathrm{~mm}$ である。Fig. 7 に示寸基本性能評価試験 機と比べ，大幅な小型化を実現した。

\section{4 ポンプ性能評価試験}

Fig. 8 に示す水実験回路を組んで実験を行った。実 験回路には二つのオーバーフロータンクを用いた。

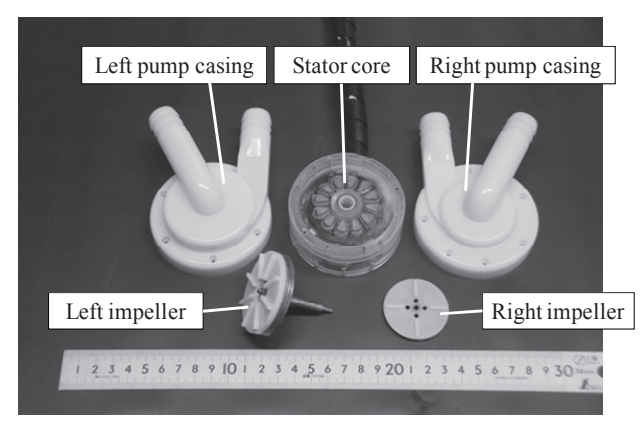

Fig. 5 Disassemble view of the IB-Heart.

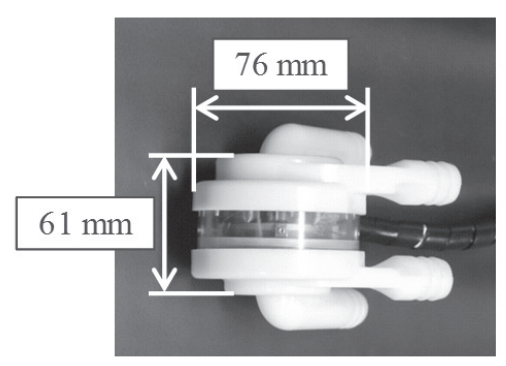

Fig. 6 Assembled view of the IB-Heart.

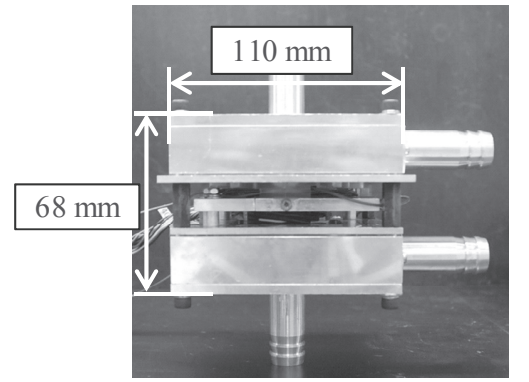

Fig. 7 Previous prototype pump for performance test.

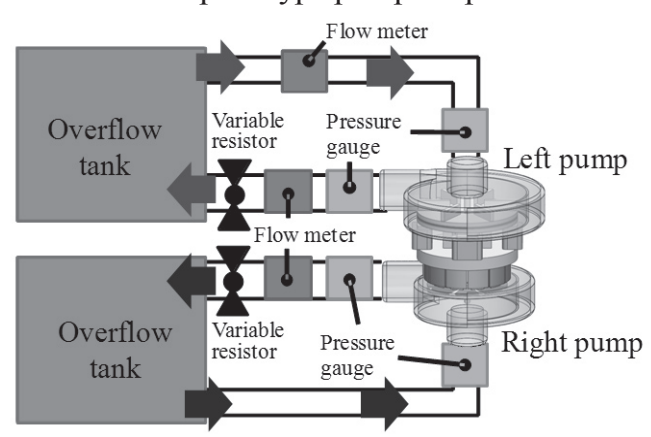

Fig. 8 Mock circulation loop. 
Table 1 Gap length between pump casing and impeller. (unit: mm)

\begin{tabular}{|c|c|c|}
\hline & Left pump & Right pump \\
\hline Position (a) & 0.2 & 0.6 \\
\hline Position (b) & 0.6 & 0.2 \\
\hline
\end{tabular}

(1) 左右流量調節試験

浮上インペラの回転数を $2100 \mathrm{rpm}$ とし, 左右各ポン プのアウトレットに取り付けた絞り抵抗により流量を 変化させることにより, 各ポンプの $\mathrm{HQ}$ 特性を評価し た。このとき, 左右の入口圧 (心房圧) は $10 \mathrm{mmHg}$ 一定とした。また, 浮上インペラの軸方向位置を変更 して浮上インペラの軸方向位置と左右のポンプ性能の 関係を評価した。浮上インペラの軸方向位置を Table 1 に示す。表中の各数字は各浮上位置における左右のポ ンプとインペラの間隙を示している。位置(a), (b) は, Fig. 4 と対応している。

（2）ウォッシュアウト流量計測試験

バランスホール[10]の有無とウォッシュアウトチャ ネル部の流量の関係を明らかにするための実験を行っ た。左右のインペラのバランスホールの有無を変更し, 各条件における左心ポンプインレット流量と左心ポン プアウトレット流量の差を算出してウォッシュアウト 流量とした。浮上インペラをゼロパワー制御によって 浮上させ，左右ポンプの揚程をそれぞれ $100 \mathrm{mmHg}$,

$20 \mathrm{mmHg}$ の一定に保ち, オーバーフロータンクの水 位を調節することで左右の心房圧を変更した。回転数 は $2100 \mathrm{rpm}$ である。

（3）FB 感受性評価実験

(2) の実験と同様の条件において，右心インペラの みにバランスホールを設けて実験を行い, 左右の心房 圧の差と FB 感受性の関係を評価した。また, 連結口 ッドの径を $6 \mathrm{~mm}$ から $10 \mathrm{~mm}$ 間で変更し, 連結ロッド の断面積と FB 感受性の関係を評価した。

\section{3 ポンプ性能試験結果および考察}

\section{1 左右流量調節試験}

Fig. 9 に, 浮上インペラ回転数 $2100 \mathrm{rpm}$, 浮上位置 が (a)，(b) のときの HQ 特性を示す。左心ポンプは, 揚程 $100 \mathrm{mmHg}$ に対し, 浮上位置 (a) のときに流量 7.0 $\mathrm{L} / \mathrm{min}$, 浮上位置 (b) のときに流量 $6.1 \mathrm{~L} / \mathrm{min}$ であった。
右心ポンプは, 揚程 $20 \mathrm{mmHg}$ に対し, 浮上位置 (a) の ときに流量 $6.4 \mathrm{~L} / \mathrm{min}$, 浮上位置 (b) のときに流量 7.2 $\mathrm{L} / \mathrm{min}$ であった。浮上インペラの浮上位置を $0.4 \mathrm{~mm}$ 変 位させることにより, 左右のポンプとも, 全流量の 20\%程度流量を調節可能であることを確認した。本ポ ンプ性能は全置換型人工心臓として十分なポンプ性能 である。今後は, 数值流体解析を用い, 左右のポンプ の流量特性を合わせるとともに，ポンプ性能のさらな る向上を得るために, インペラ形状の検討を行う。

3.2 ウォッシュアウト流量計測実験

11 に, バランスホールの有無とウォッシュアウト流 量の関係を示す。凡例は左右のインペラのバランスホ 一ルの有無を示している。流量は, 左心ポンプ側から 右心ポンプ側へ流れる向きを正の流量としている。

左心インペラにバランスホールが無い場合は, ウォ ッシュアウト流量は心房圧の差に大きく影響されるこ となく, 左心ポンプ側から右心ポンプ側へ $1.2 \sim 1.5$ L/min 流れた。一方, 左心インペラにバランスホール が有る場合, ウォッシュアウト流量は著しく低下し, 場合によっては右心から左心几逆流寸る流れとなった。 同部の流量が小さいと, 流れの停滞により血栓を形成 しや寸くなる。また, 右心ポンプ側の血液は, 酸素化 前の静脈血であるため, 左心に逆流寸ると血液酸素濃 度が低下寸る。よって, 左心インペラにはバランスホ 一ルを設けないことが望ましい。

\section{3 連結ロッド断面積と FB. 感受性の関係}

に連結ロッド断面積と FB. 感受性の関係を示す。連 結ロッド径を $6 \mathrm{~mm}$ から $8 \mathrm{~mm}$ に変更すると, 連結口 ッド断面積はおよそ 1.8 倍となり, FB.感受性は

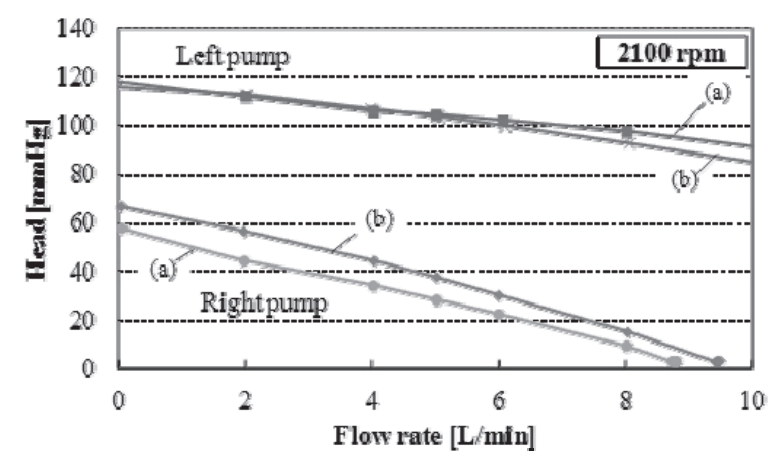

Fig. 9 Pump characteristics change due to axial position changing of the levitated impeller. 


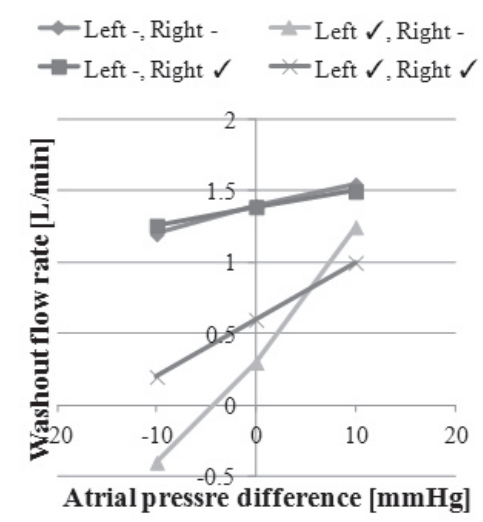

Fig. 10 Relationship between balance hole. and washout flow rate

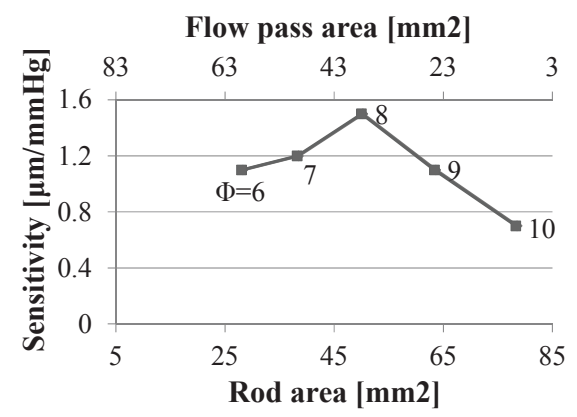

Fig. 11 Relationship between road area and FB sensitivity.

$36 \%$ 増加した。ここで, ポンプ内の圧力分布について 考察する。Fig. 12 にポンプ断面図とポンプ内圧力分布 を示す。図は, 紙面上部側が左心ポンプ, 下部側が右 心ポンプである。IB-Heart では, 連結ロッド周りの血 栓形形成防止のために, 連結ロッド周りのウォッシュ アウト流路に血液を左心から右心に向けて流寸，その ため, 左心インペラにはインペラ表裏を貫通し表裏の 圧力を等しく保つバランスホールは設けていない。一 方，右心ポンプのインペラにはバランスホールを設け た。よって, 右心インペラ裏面の中央部は右心房圧に 近い圧力となるが, 左心ポンプ裏面には, 左心出口圧 が導入され, 常に左右心間で圧勾配が生じ, ウォッシ ユアウト流路内に血液流れが生じることになる。一方, ウォッシュアウト流路を介して左心インペラ裏面中央 は右心インペラの裏面とつながるため, 右心房圧の影 響を受ける。そのため, 左心インペラの表裏両面の圧 力分布はほぼ同じ分布をとっていると仮定すると, 左 右心の浮上インペラにかかる軸方向の流体力は, 連結 ロッド接続面を除き, 各インペラの上下で打ち消し合 うこととなる。よって, 左右の心房圧の圧力差により 生じる流体力は連結ロッドの断面積に比例し, FB. 感受 性も同様に比例すると考えられる。
一方，連結ロッド径が $8 \mathrm{~mm}$ を超えると，周囲の流 路断面積が $40 \mathrm{~mm}^{2}$ を下り, FB 感受性は急激に低下し た。これは, ロッド周囲の流路断面積が小さくなるこ とにより，同部の管路抵抗が急激に高くなり，ポンプ 内の圧力分布が変化したためであると考えられる。そ のため, より高い FB 感受性を得るためには, ロッド 周囲の流路断面積を $40 \mathrm{~mm}^{2}$ 以上に保ちつつ，ロッド 断面積を拡大寸る必要がある。

\section{4 磁気浮上モータの再設計}

上記評価試験結果より, 連結ロッド断面積の増加を 目指して，ステータコア中心穴径の拡大を主目的に磁 気浮上モータの再設計を行った。本ポンプの左右心流 量バランス制御ではゼロパワー制御を用いるため, 磁 気浮上モータ形状の変化にともなう負ばね特性の変化 に応じて FB 感受性が変化する。今回の設計では, 設 計後の磁気浮上モータが現在のものと同等の負ばね特 性を有するように磁気軸受およびモータ形状を変更す ることで，形状の変更が FB 感受性へ影響を与えない ようにすること, モータ効率の向上を図ることを目標 に 3 次元磁場解析を行った。

ステータコア内径を $20 \mathrm{~mm}$ 以上に拡大する場合に は，ステータの内側突極と，それに対向するロータデ イスクの永久磁石の幅を狭める必要がある。そこで, ステータ突極と永久磁石の対向面積の減少による磁気 吸引力の低下を防ぐため, ステータ内側突極の形状を 円環形とした。同時に，モータトルクの向上を図るた め, モータ外径を $40 \mathrm{~mm}$ から $50 \mathrm{~mm}$ に変更すると共 に，突極間の幅であるスロット幅を $4 \mathrm{~mm}$ から $5 \mathrm{~mm}$ に拡大し, コイル巻き数を 60 から 80 に変更し, 3 次 元磁場解析でその効果を検証した。

Fig. 13に再設計前後の磁気浮上モータのステータ形 状を示す。Table 2 に, 再設計前後の磁気軸受の寸法と 解析結果を示す。再設計した磁気軸受は内径が $24 \mathrm{~mm}$ であり, 改良前のモデルの 1.6 倍である。また, 力係

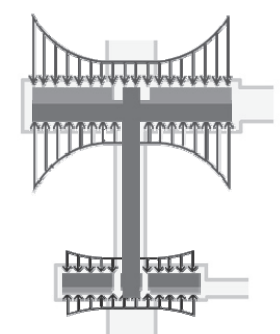

Fig. 12 Pressure distribution on the impeller surface. 
数 $[\mathrm{N} / \mathrm{A}]$ （制御電流 $1 \mathrm{~A}$ で変化させられる軸方向吸引 力の大きさ）は本改良により $10 \%$ 程度向上する。軸 方向磁気吸引力の大きさは保ったまま, 内径と力係数 の拡大を行うことができた。

Table 3 に, 再設計前後のモータの寸法と解析結果を 示す。これらの変更により, トルク定数は, 再設計前 の $29.8 \mathrm{mNm}$ から $40.4 \mathrm{mNm}$ に, 約 36\%向上した。磁 気浮上系のバイアス磁気吸引力とバランスさせるため, 軸方向磁気吸引力は, 再設計前のモデルと同等の大き さを保った。

以上の再設計により, 磁気浮上モータのステータ内 径を $24 \mathrm{~mm}$ に拡大寸ることができ, カプセル化後のウ オッシュアウトチャネルの内径は $20 \mathrm{~mm}$, 連結ロッド の径は $19 \mathrm{~mm}$ まで拡大可能となった。これより, 連結

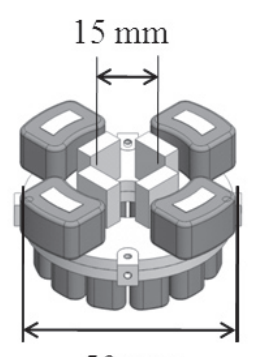

$50 \mathrm{~mm}$ Current model

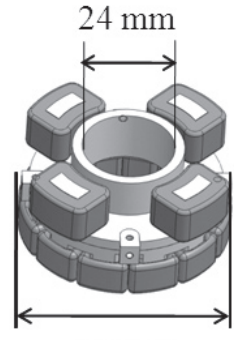

$50 \mathrm{~mm}$ Improved model
Fig. 13 The structure of stator.

Table 2 Configuration and analysis result of new MB.

\begin{tabular}{|c|c|c|c|}
\hline & & Current model & New model \\
\hline Stator inner diameter & {$[\mathrm{mm}]$} & 15 & 24 \\
\hline Rotor inner diameter & {$[\mathrm{mm}]$} & 15 & 24 \\
\hline Width of inner pole & {$[\mathrm{mm}]$} & 4.5 & 2.5 \\
\hline Width of inner 2nd PM & {$[\mathrm{mm}]$} & 4.5 & 2.5 \\
\hline Coil turns & {$[-]$} & 200 & 200 \\
\hline Inner pole shape & {$[-]$} & Rectangular & Cylindrical \\
\hline Attractive force & {$[\mathrm{N}]$} & 28.6 & 28.5 \\
\hline Force index & {$[\mathrm{N} / \mathrm{A}]$} & 7.0 & 7.6 \\
\hline
\end{tabular}

Table 3 Configuration and analysis result of new motor.

\begin{tabular}{|c|c|c|c|}
\hline & & Current model & New model \\
\hline Inner diameter & {$[\mathrm{mm}]$} & 40 & 50 \\
\hline Outer diameter & {$[\mathrm{mm}]$} & 24 & 38 \\
\hline Slot width & {$[\mathrm{mm}]$} & 4.0 & 5.0 \\
\hline Coil turns & {$[-]$} & 60 & 80 \\
\hline Attractive force & {$[\mathrm{N}]$} & 21.4 & 21.4 \\
\hline Torque constant & {$[\mathrm{mNm} / \mathrm{A}]$} & 29.8 & 40.4 \\
\hline
\end{tabular}

ロッド断面積，FB.感受性は初期モデルのおよそ 10 倍 となると考える。

今後は実機を製作し，実際の磁気浮上モータの性能 と FB.感受性の向上を確認する。また，負荷が変動す る際や浮上インペラの回転数を変動させる拍動運転時 の浮上インペラのダイナミックな挙動について検討す る。

\section{5 結言}

全置換型磁気浮上人工心臟 IB-Heart の試作機を製作 し, 浮上インペラの軸方向位置の変化に伴ってポンプ 流量が変化すること, 心房圧の変化に応じて浮上イン ペラの軸方向位置が原理通りに変化することを確認し た。現状の性能を保ったまま, 流量バランス感受性を 10 倍に拡大できる磁気浮上モータを再設計した。

(2014 年 3 月 24 日受付, 2014 年 9 月 30 日再受付)

\section{参考文献}

[1] 増澤徹, 人工心臓: 医用アクチュエーションの最前線, ヘルスケアとバイオ医療のための先端デバイス機器三林 浩二監修，シーエムシー出版，pp. 316-325, 2009.

[2] 電気学会技術報告第 1122 号「医用アクチュエーション技 術の現状」医用アクチュエーション技術に関する共同研 究委員会編, 2008

[3] Stephen Westaby and Gabriele B. Bertoni, Destination Therapy, Mechanical Circulatory Support, pp.43-49, 2012

[4] Lyle D. Joyce, Bridge-to-Ttansplantation, Mechanical Circulatory Support, pp.50-55, 2012

[5] Dang Nc, Topkara VK, Mercando M, et al., Right heart failure after left ventricular assist device implantation in patients with chronic congestive heart failure, J Heart Lung Transplant, 25, pp.1-6, 2005

[6] 山田悠, 増澤徹，D. L. Timms ゼロパワー制御を用いた 磁気浮上全人工心臟の流量バランス制御，電気学会リニ アドライブ研究会資料，LD-13-083，2013

[7] 増澤徹, 小沼弘幸, 岡田養二, 他, 磁気浮上遠心ポンプ内 の流体力とゼロパワー制御，日本機械学会流体工学部門 講演会講演論文集, 718, 2004.

[8] 増澤徹, 佐々木瑛祐, D. L. Timms, 両心補助人工心臟 BiVACOR Bi-VAD 用磁気浮上モー夕, 日本 AEM 学会誌, 18, 2, pp.78-84, 2010.

[9] Arthur C. Guyton, John E.Hall, ガイトン生理学, p.273, 2010 [10]西田正浩, 山根隆志, A.Aouidef, 他, 送血用遠心ポンプ 内流れに対するウォッシュアウトホール形状の効果, 日 本機械学会年次大会講演論文集, Vol.2000, No.1(20000731), pp.305-306 